\section{Barnenevrologi for frakkelommen}

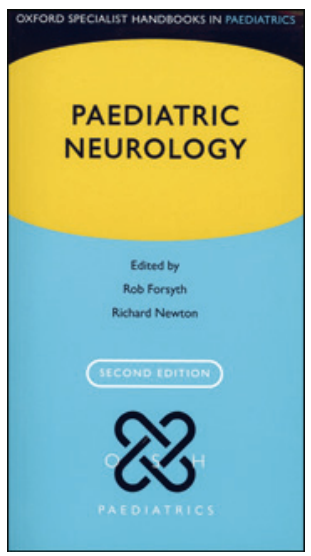

Rob Forsyth, Richard W. Newton, red. Paediatric neurology

2. utg. 633 s, tab, ill. Oxford: Oxford University Press, 2012. Pris GBP 40

ISBN 978-0-19-960363-3

Barnenevrologi utgjør en viktig del av pediatrien og griper inn i andre fag, særlig nevrologi, barnepsykiatri, biokjemi og genetikk. Denne håndboken er et kjærkomment hjelpemiddel for klinikere $i$ en travel hverdag. Formatet passer fint i frakkelommen, og ordlisten er rikholdig, slik at det er fort gjort å slå opp på rett problemstilling.

Stoffet er delt inn i sju kapitler: klinisk nevrologisk undersøkelse - også av nyfødte, nevroradiologi, tegn og symptomer ved vanlige problemstillinger, spesifikke tilstander og diagnoser, samarbeid med andre spesialiteter, akutte nødsituasjoner og farmakologi.

Undertegnede har brukt boken flittig i den senere tid og føler virkelig at den har vært til nytte, særlig kapitlene om symptomer og diagnoser. Symptomkapitlet gjenspeiler de fleste problemer som er gjenstand for henvisning til barnenevrologisk poliklinikk, f.eks. atferdsforstyrrelse, hodepine, ulike former av anfall, hypotoni og muskelsvakhet, ustøhet og psykomotorisk tilbakegang. For psykomotorisk tilbakegang finnes det oversiktlige tabeller for et utvalg aktuelle sykdommer relatert til hvilke alderstrinn de debuterer. I diagnosekapitlet går forfatterne inn på hvordan de enkelte sykdommene kan diagnostiseres, og hvilke tilstander som er assosiert med spesifikke symptomer og tegn.

Bruken av kryssreferanser er utbredt og virker svært effektiv, slik at det er enkelt å slå opp på forskjellige steder der samme tegn/ symptom eller diagnose er nevnt, men fra ulike synsvinkler. Boken er også rikt illustrert med algoritmer. De fleste lærebøker i dag må leve i konkurranse med nettsteder, men jeg tror at lommeformatet, de nøye gjennomarbeidede kryssreferansene og forfatternes personlige anbefalinger gjør at boken føles relevant og fint kan konkurrere med elektroniske kilder.

Petter Strømme

Barneavdeling for nevrofag

Kvinne- og barneklinikken

Oslo universitetssykehus, Ullevål

\section{Matnyttig app om legevaktarbeid}

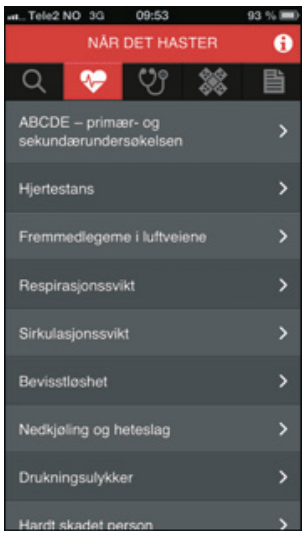

Ingrid H. Johansen, Jesper Blinkenberg, Cecilie Arentz-Hansen et al, red.

Legevakthåndboken

4. utg. Gyldendal Akademisk, 2012. Pris gratis

Legevakthåndboken ble først gitt ut i 1993 og har vært til hjelp for mang en legevaktslege siden. Dette oppslagsverket har nå kommet i 4. utgave og er gratis tilgjengelig både som app og på nettsiden www.lvh.no.

Tilgjengeligheten den presenterer som app, er uovertruffen. De som har brukt den opprinnelige Legevakthåndboken, vil også kjenne igjen det oppdaterte verket. De opprinnelige kapitlene er stort sett beholdt.

Menyen er delt i fem: Søk, Når det haster, Symptomer og sykdom, Skader og Administrative forhold. Totalt er disse delt inn i 52 underkapitler. Kapitlene er korte og oversiktlige, og menyen er lett å manøvrere i - i hvert fall med Iphone 5, som jeg har testet den på.

Dette oppslagsverket er nyttig først og fremst for leger som driver legevaktsarbeid, men i og med at det er et såpass bredt verk, vil sykehusleger også kunne finne aktuelle kapitler. Håndboken er ikke ment å være en lærebok, og de ulike emnene omtales ikke dyptgående, men er derimot tiltaksorienterte.

I den nye utgaven er alle kapitlene blitt gjennomgått av relevante spesialister og fagmiljøer med spisskompetanse. Det er ikke gjort en systematisk gjennomgang av litteraturen for hvert kapittel, men stoffet er kvalitetssikret opp mot UpToDate, BMJ Best Practice, Norsk elektronisk legehåndbok og faglige veiledere for grenspesialiteter. Nasjonale faglige veiledere er integrert der det er relevant.

Legevakthåndboken er innarbeidet som oppslagsverk for alle leger/studenter som er involvert i allmennmedisin og legevakt. Den oppdaterte versjonen er gratis på nett og som app, og kan anbefales.

\title{
Kenneth Thorsen
}

Kirurgisk avdeling

Stavanger universitetssjukehus 